\title{
What are the barriers to learners' satisfaction in MOOCs and what predicts them? The role of age, intention, self-regulation, self-efficacy and motivation
}

\author{
Eyal Rabin \\ Open University of the Netherlands; The Open University of Israel
}

\author{
Maartje Henderikx \\ Open University of the Netherlands
}

Yoram M. Kalman

The Open University of Israel

\author{
Marco Kalz \\ Heidelberg University of Education; Open University of the Netherlands
}

\begin{abstract}
Massive open online course (MOOC) participants face diverse barriers that prevent them from feeling satisfied with participating in online courses. This study identified those barriers and their predictors. Using pre- and post-questionnaires, MOOC participants reported several characteristics and their barriers to satisfaction during the course. Exploratory factor analysis identified three kinds of barriers. The effects of participants' age, gender, level of selfefficacy, motivation, self-regulated learning skills and the intention to complete the course were used as predictors of those barriers to satisfaction. The barrier lack of interestingness/relevance was predicted by the self-regulation indices of self-evaluation, study-strategy and help-seeking. The barrier lack of time/bad planning was predicted by the self-regulation indices of goal setting, time management and study strategy and by the age of the respondent. The barrier lack of knowledge/technical problem was predicted by the level of self-efficacy, extrinsic motivation and the self-regulation index of time management, as well as by the behavioural intention to complete the course. Furthermore, an index averaging the extent of the barriers was predicted by the self-regulation indices of goal setting and study strategy, the level of self-efficacy and the level of extrinsic motivation. Theoretical and practical implications are discussed in order to help MOOC participants, instructors and designers to enhance learner satisfaction.
\end{abstract}

Implications for practice or policy:

- Course developers and online instructors should be aware that participants in MOOCs face a variety of barriers that keep them from being satisfied with the learning process and learning outcomes.

- Practitioners should develop specific interventions for young participants and participants with fewer learning experience in MOOCs.

- $\quad$ MOOC designers and instructors should develop tailored systems and resources that help MOOC participants to self-regulate their learning process and to improve their selfefficacy.

Keywords: MOOCs, satisfaction, self-efficacy, self-regulated learning, motivation, intentions, learners' barriers

\section{Introduction}

Learners who enrol in massive open online courses (MOOCs) selectively engage in parts of the course content, and a small proportion eventually completes the course (Breslow et al., 2013; Ho et al., 2015; Reich \& Ruipérez-Valiente, 2019). Several authors have recently suggested adapting the perspective on learning in MOOCs to the realm of non-formal education (Rabin, Kalman, \& Kalz, 2019a) and proposed that the success of lifelong learning in MOOCs should be evaluated through learner-centred measures such as learner satisfaction from participating in the course (Rabin et al., 2019a; Reich, 2014). Online learning satisfaction has been emphasised by the American Distance Education Consortium as the most important 
element defining students' online learning success experience (Horvat, Dobrota, Krsmanovic, \& Cudanov, 2015; Naveh, Tubin, \& Pliskin, 2012). In addition, online learner satisfaction is one of the five elements for evaluating the quality of online learning identified by the Online Learning Consortium (Alqurashi, 2019). Learner satisfaction reflects students' perception of their learning experience (Alqurashi, 2019; Kuo, Walker, Schroder, \& Belland, 2014; Littlejohn, Hood, Milligan, \& Mustain, 2016) and is defined as the student's overall positive assessment of the learning experience (Keller, 1983). Research has found positive correlations between student satisfaction and post-secondary student success (Chang \& Smith, 2008), the intention to use e-learning (Liaw \& Huang, 2011; Roca, Chiu, \& Martínez, 2006), retention in an online course (Lee \& Choi, 2013; Levy, 2007; Park \& Society, 2009), dropout rates of students and motivation and commitment to complete a degree online (Ali \& Ahmad, 2011; Yukselturk \& Yildirim, 2008).

The unstructured, self-paced nature of the MOOC learning environment creates unique types of barriers in the learning process, which can affect the level of satisfaction of the participants. This research focused on those barriers and on their predictors. The goal was to reveal the barriers to satisfaction that MOOC participants face and the antecedents to these barriers.

In the current study, we adapted the definition of barriers to learning from Henderikx, Kreijns, and Kalz (2018), which resulted in the following definition: barriers to learner satisfaction are issues that hinder or prevent learners from reaching their individual intentions and that harm their level of satisfaction. This type of barrier might differ from barriers in traditional education, due to the online and non-committed nature of MOOC learning and may be related to the MOOC itself, for example, bad course content, low quality of the course materials, or the absence of the instructor. Alternatively, the barriers may be extraneous to the MOOC or to the MOOC environment, for example, lack of time, insufficient academic background, family issues, workplace commitments, and insufficient technological background (Henderikx et al., 2018; Khalil \& Ebner, 2014; Onah, Sinclair, \& Boyatt, 2014). Predicting the barriers that learners can encounter enables course designers to tailor their design to specific needs, as well as prevent the implementation of unnecessary interventions. Moreover, being aware of the antecedents to the barriers can help learners to anticipate and prevent encountering those barriers or to overcome them with support from personalised, tailor-made assistance tools.

\section{Barrier antecedents}

Participants' age can affect the occurrence of barriers. In a recent study, Henderikx, Kreijns, Muñoz, and Kalz (2019) analysed predictors of barriers to learning in MOOCs. They used the perspective of life stages theory (Stoffelsen \& Diehl, 2007) and identified several external barriers that are most prominent in specific age ranges. Their analysis indicated that learners in their early adulthood (20-35 years) and mid-life (3650 years) most often faced external barriers such as family and work issues. Learners in their mid-life stage (36-50 years) comprise the group most hindered by these issues.

Previous studies have found significant differences in learning, attitudes, motivation, and experiences of online learning, which were associated with the gender of the participant. Some recent studies (e.g., Garrido, Koepke, Anderson, and Mena, 2016) found that women are more likely than men to complete a MOOC or to obtain certification. On the other hand, other studies did not identify the influence of gender on achievement or on completion rates (Breslow et al., 2013; Cisel, 2014; Kizilcec, Piech, \& Schneider, 2013; Morris, Hotchkiss, \& Swinnerton, 2015). Using learner-centred indices for assessing success in MOOCs, Rabin et al. (2019a) found that gender correlated with the level of intention-fulfillment, but not the level of satisfaction. Female participants reported a higher level of intention fulfillment than males, but there were no differences between female and male participants in the level of learner satisfaction. Regarding barriers to online learning, Muilenburg and Berge (2007) found that men rated barriers of administrative issues, time and support more highly than women. Henderikx et al. (2019) found that female learners faced more barriers related to work-life balance than men, although they did not find significant differences across gender in the number of barriers for pursuing personal learning goals in MOOCs in general. In conclusion, we are not aware of evidence that shows that gender is associated with barriers to satisfaction in MOOCs.

According to the theory of planned behaviour, intentions are the most important predictors of behaviour (Ajzen, 1991). Several studies have shown that pre-course intentions of MOOC participants can predict the actual behaviour of the participants and their post-course evaluation (Koller, Ng, Do, \& Chen, 2013; Reich, 
2014; Wang \& Baker, 2018). For example, Wang and Baker (2018) showed that learner intention to earn a certificate was positively associated with actually earning a certificate in a MOOC. However, in many cases, the intention is formed, but cannot be realised due to certain barriers which impede performance (Henderikx et al., 2018).

Another factor that influences learning outcomes and post-course evaluation is the ability of learners to self-regulate their learning (Kizilcec, Perez-Sanagustín, \& Maldonado, 2017; Rabin et al., 2019a; Zalli, Nordin, \& Hashim, 2019). Zimmerman (2000) defined self-regulation as self-generated thoughts, feelings, and actions that are planned and cyclically adapted towards the attainment of personal goals. Highly selfregulated learners are characterised by their higher ability to initiate metacognitive, cognitive, affective, motivational and behavioural processes in order to take actions to achieve their learning goals and persevere until they succeed (Zimmerman, 2002). In the absence of support and guidance in self-paced courses, the ability to regulate the learning process is a critical skill for achieving personal learning objectives. Online learners need to determine when, where and how to engage in course content and learning activities. Many learners struggle with self-regulation in online learning environments (Lajoie \& Azevedo, 2006). In this study, we used the six dimensions of online self-regulation that were introduced by Barnard, Lan, To, Paton, and Lai (2009): goal setting, environment structuring, task strategies, time management, help-seeking and self-evaluation.

In addition, research has found that learners who indicate higher levels of self-regulated learning (SRL) also report higher levels of motivation and commitment to learning (Littlejohn et al., 2016; Margaryan, Bianco, \& Littlejohn, 2015). Motivation is the process that initiates, guides and maintains goal-oriented behaviour (Ryan \& Deci, 2000). According to these authors, motivation can be understood as a continuum between intrinsic motivation (defined as an active engagement with tasks because of self-desire to seek out new things and new challenges and to gain knowledge and fun) and extrinsic motivation (defined as the regulation of the activity as a function of expectations regarding reward and punishment).

Another factor which is known to affect learner behaviour and learning outcomes is the level of self-efficacy of the learner. Self-efficacy is defined as the belief that a task is achievable and that the environment in which one works enables one to achieve that task (Brennan, 2013). Students with high self-efficacy do not regard difficult tasks as obstacles to avoid, but rather as a challenge in order to develop their skills. Selfefficacy can enhance learning and performance and lead to higher satisfaction with the achieved results (Alqurashi, 2016). Online learning self-efficacy has been found to be a predictor of student satisfaction in online courses (Artino, 2007; Shen, Cho, Tsai, \& Marra, 2013). According to the reasoned action approach (Fishbein \& Ajzen, 2011) and self-determination theory (Ryan \& Deci, 2000), participants' self-efficacy and level of motivation directly affect their learning behaviour.

As these factors are generally known to affect learning outcomes and learner behaviour, it can be expected that they will also have an impact on experiencing barriers to satisfaction. Although the studies mentioned have focused on factors influencing the barriers MOOC participants experience, or on their level of satisfaction, this study specifically focused on the role of age, gender, learner intention, level of selfefficacy for learning, level of motivation and level of self-regulation in the prediction of barriers to satisfaction in MOOCs. This led to the following two research questions:

- What types of barriers to satisfaction do MOOC participants encounter?

- How do age, gender, learner intention, level of self-efficacy for learning, level of motivation and level of self-regulation affect the barriers to satisfaction that MOOC participants encounter?

\section{Method}

\section{Participants}

Participants in this study were 542 English as a second language (ESL) MOOC learners. The participants answered a pre- and post-questionnaire at the beginning and at the end of their learning period. The prequestionnaire was sent online via email to the MOOC participants when they logged into the course for the first time. After reading about the research goals and signing an informed consent form, participants responded to the pre-questionnaire. Four months after having filled the pre-questionnaire, a postquestionnaire was emailed to all the participants. The data collection ran between July 2016 and February 
2018. The course was free of charge, and there were no prerequisites. The MOOC participants were able to join and leave the MOOC whenever it suited them. Most participants (71\%) were female. The mean age of the sample was 32.4 years $(S D=11.70$; age range: $18-81$ years $)$.

\section{Instruments and procedure}

Dependent variable

The MOOC participants were asked at the end of the course (post-questionnaire) to rate 12 barriers to satisfaction that they might have faced during the course. The list of barriers was adapted from Henderikx, Kreijns, and Kalz (2017) and Henderikx et al. (2018), and the items were rated on a Likert scale ranging from 1 (not at all) to 7 (fully). Table 1 present the items in the questionnaire.

To answer the first research question ("What types of barriers to satisfaction do MOOC participants encounter?"), we used an exploratory factor analysis with Varimax rotation due to the orthogonal nature of the factors (Gannon-Cook, 2010).

The exploratory factor analysis of the 12 barriers listed in the survey revealed three factors that accounted for $65.73 \%$ of the overall variance. The data set was examined for factor analysis adequacy, which was found to be satisfactory (Kaiser-Meyer-Olkin $=.86$, Bartlett's Test of Sphericity $=2775, d f=66, p<.001$ ) (Field, 2005). The three factors that were identified are:

- lack of interestingness/relevance (barriers related to the quality of the learning resources, appeal of the course or of the certification options)

- lack of time/bad planning (barriers related to time planning, capacity for spending time)

- lack of knowledge/technical problems (barriers related to the high amount of information in the course, complexity of the course structure, technical problems or lack of prior knowledge).

These three factors corresponded reasonably well with the classification by Henderikx et al. (2018) - Factor 1 is similar to social context (Component 2), Factor 2 is similar to time, support and motivation (Component 4) and Factor 3 is similar to technical and online-learning related skills (Component 1).

Factor scores were calculated for each of the three factors identified, by averaging the items that make up the factor. Also, an overall index score was calculated by averaging all 12 items. The overall index score of barriers represents the extent to which participants perceived they faced barriers that prevented them from feeling satisfied with their learning experience in the MOOC.

Low to medium correlations were found between the three factors, indicating that although the barriers have some common features, they reflect different obstacles, and their different antecedents should be revealed (Pearson correlation ranging from .28 to $.57, p<.001$ ). Table 1 shows the mean, standard deviation and the factor loading of the 12 barriers.

\section{Independent variables}

To assess the characteristics of the participants, an online pre-course questionnaire was administered at the beginning of the course. The questionnaire consisted of the following parts:

- Demographics - Participants reported about their gender and age.

- Intention to complete the course activities - This was a single item asking about the behavioural intention of the participant to complete the course on 3-point nominal scale: I plan to complete some portion of the course, I plan to complete all the course parts, or I do not know yet.

- $\quad$ Self-efficacy for learning and performance - The Motivated Strategies for Learning Questionnaire (MSLQ, Pintrich, 1991). The questionnaire included eight items measuring self-efficacy for learning and performance on a 7-point Likert scale (Cronbach's alpha $=.93$ ).

- Motivation - The Motivated Strategies for Learning Questionnaire (MSLQ, Pintrich, 1991) includes four items for measuring internal motivation (Cronbach's alpha $=.76$ ) and four items for measuring external motivation (Cronbach's alpha $=.70$ ). The items were rated on a 7-point Likert scale. 
- Online SRL skills - Six indices measuring online learning self-regulation were adapted from the online learning self-regulation questionnaire (OLSQ, Barnard et al., 2009). The indices were goal setting, environmental structuring, learning strategies, time management, seeking help and selfevaluation. All the items were measured on a 7-point Likert scale (Cronbach's alpha ranged from .71 to .85$)$.

Table 1

Results of the exploratory factor analysis for the 12 barrier items

\begin{tabular}{|c|c|c|c|c|c|}
\hline Constructs and their component items & Mean & $S D$ & Loadings & $\begin{array}{c}\% \text { of } \\
\text { overall } \\
\text { variance }\end{array}$ & $\begin{array}{l}\text { Cronbach's } \\
\text { alpha }\end{array}$ \\
\hline Barrier-general score & 2.62 & 1.17 & & 65.73 & .86 \\
\hline $\begin{array}{l}\text { Factor } 1 \text { - Lack of } \\
\text { interestingness/relevance }\end{array}$ & 2.58 & 1.35 & & 25.83 & .83 \\
\hline $\begin{array}{l}\text { The course content did not meet my } \\
\text { expectations }\end{array}$ & 2.82 & 1.78 & .81 & & \\
\hline The course was not interesting & 2.58 & 1.65 & .81 & & \\
\hline The course was not relevant to me & 2.51 & 1.76 & .81 & & \\
\hline $\begin{array}{l}\text { The course did not provide any } \\
\text { certificate }\end{array}$ & 2.78 & 2.05 & .58 & & \\
\hline The quality of the course was low & 2.11 & 1.52 & .67 & & \\
\hline Factor 2 - Lack of time/bad planning & 3.19 & 1.80 & & 20.22 & .87 \\
\hline I had less time than I expected & 3.25 & 2.02 & .85 & & \\
\hline Other stuff distracted my mind & 3.10 & 1.94 & .81 & & \\
\hline I was not able to plan my time & 3.15 & 2.06 & .89 & & \\
\hline $\begin{array}{l}\text { Factor } 3 \text { - Lack of knowledge/technical } \\
\text { problem }\end{array}$ & 2.18 & 1.24 & & 19.69 & .77 \\
\hline The course was too complicated for me & 2.16 & 1.56 & .79 & & \\
\hline $\begin{array}{l}\text { The course overwhelmed me with lots } \\
\text { of information }\end{array}$ & 2.19 & 1.58 & .82 & & \\
\hline $\begin{array}{l}\text { I had a technical problem with my } \\
\text { computer, Internet connection or the } \\
\text { website }\end{array}$ & 1.92 & 1.56 & .58 & & \\
\hline $\begin{array}{l}\text { I lack the skills and knowledge to pass } \\
\text { the course }\end{array}$ & 2.47 & 1.77 & .58 & & \\
\hline
\end{tabular}

\section{Results}

To answer the second research question, as to which extent participants' characteristics affect the different barriers, four prediction models were created: one in order to identify the predictors of the overall barrier score index and three to identify each of the predictors of the three indices of barriers that were identified in the answer to the first research question.

In all four models, a stepwise linear regression model assisted in revealing the predictors of each factor. The independent variables were age, gender, level of self-efficacy, level of internal and external motivation, level of the six indices of SRL and level of behavioural intention (learner intention). The level of learner intention was coded into two dummy variables - the first dummy variable compared between those who intended to complete all parts of the course with those who intended to complete only some parts of the course or did not know how many parts they would complete of the course. The second dummy variable compared those who did not know how many parts they would complete of the course with those who intended to complete some or all parts of the course. Table 2 presents the regression coefficients and the summaries of the four prediction models. Only statistically significant results are reported. 
Table 2

Results of the stepwise linear regression for the association of age, intention to complete, SRL, self-efficacy and motivation with the participant barriers

\begin{tabular}{|c|c|c|c|c|}
\hline & $\begin{array}{c}\text { General } \\
\text { score }\end{array}$ & $\begin{array}{c}\text { Factor 1; } \\
\text { Lack of } \\
\text { interestingness/relevance }\end{array}$ & $\begin{array}{l}\text { Factor 2: } \\
\text { Lack of } \\
\text { time/bad } \\
\text { planning }\end{array}$ & $\begin{array}{c}\text { Factor 3: } \\
\text { Lack of } \\
\text { knowledge/technical } \\
\text { problem }\end{array}$ \\
\hline Predictors & Beta & Beta & Beta & Beta \\
\hline Age & - & - & $-.09 *$ & - \\
\hline $\begin{array}{l}\text { Intention to } \\
\text { complete - all parts } \\
\text { vs. do not know } \\
\text { yet/parts of the } \\
\text { course }\end{array}$ & & & & $-.10 *$ \\
\hline SRL - goal setting & $-.16 * *$ & - & $-.26 * * *$ & - \\
\hline $\begin{array}{l}\text { SRL - self- } \\
\text { evaluation }\end{array}$ & - & $-.20 * * *$ & - & - \\
\hline SRL - help seeking & - & $.24 * * *$ & - & - \\
\hline $\begin{array}{l}\text { SRL - study } \\
\text { strategy }\end{array}$ & $-.15^{*}$ & $-.13 *$ & $-.15^{* *}$ & - \\
\hline $\begin{array}{l}\text { SRL - time } \\
\text { management }\end{array}$ & $.16^{* *}$ & - & $.18^{* *}$ & $.12 *$ \\
\hline Self-efficacy & $-.12 *$ & - & - & $-.23 * * *$ \\
\hline $\begin{array}{l}\text { Extrinsic } \\
\text { motivation }\end{array}$ & $.11^{*}$ & - & - & $.16^{* *}$ \\
\hline \multicolumn{5}{|l|}{ Model summary } \\
\hline Adjusted $R^{2}$ & .08 & .04 & .11 & .09 \\
\hline$F$ & $9.96 * * *$ & $6.38 * * *$ & $12.90 * * *$ & $11.08 * * *$ \\
\hline$D f$ & 5,404 & 3,404 & 4,400 & 4,401 \\
\hline
\end{tabular}

Note. Only significant predictors are presented. The predictors gender, SRL-environmental structuring, as well as the dummy variable of intention to complete - do not know yet vs. all and some parts - were not included in the table since they did not significantly predict any dependent variable. ${ }^{*} p<.05 ;{ }^{* *} p<.01$; $* * * p<.001$

The overall score of barriers was predicted negatively by the SRL indices goal setting and study strategy and the level of the participants' self-efficacy. The overall score of barriers was predicted positively by the SRL index of time management and the level of extrinsic motivation. This suggests that from a selfregulation perspective, the lower the goals that participants set for their learning process, the less they plan their learning strategy. In addition, the more participants plan how to manage their time, the more they will face barriers while taking the MOOC. Furthermore, the lower the participants' levels of self-efficacy for learning and the more they are driven to learn by external rewards, the more they will face barriers while taking the MOOC.

Factor 1, lack of interestingness/relevance, was predicted negatively by the SRL indices self-evaluation and study strategy and positively by the SRL index help-seeking. In other words, the less the participants are able to self-evaluate their learning process and to plan their strategy of learning and the more they believe that they will know how to search for help if needed, the more they will find the course not interesting or not relevant to them.

Factor 2, lack of time/bad planning, was predicted negatively by the SRL index goal setting, study strategy and the age of the respondent and positively by the SRL index time management. The less participants are able to set their learning goals and learning strategies, the more they are able to manage their own learning time, and the younger the participants are, the more they experience lack of time or bad planning.

Factor 3, lack of knowledge/technical problem, was predicted negatively by the level of the participant's self-efficacy and positively by the level of their extrinsic motivation towards participation and by the SRL index time management, as well as the initial behavioural intention. The more participants reported that 
they had a low level of self-efficacy and a higher level of external motivation and the more they reported being able to manage their own learning time, the more they faced lack of knowledge and technical problems. Those who intended to complete all the course activities faced less lack of knowledge and technical problems than the two other groups of participants: Those who intended to complete only some parts of the course activities and those who did not know how many parts of the course they would like to complete. In this model, no differences were found between participants who intended to complete only some parts of the course activities and participants who did not know how many parts of the course they would like to complete.

It is interesting to note that the gender of the participants and their level of SRL-environmental structuring did not predict any kind of barriers. Male and female participants face the same barriers while participating in a MOOC. The SRL dimension environment structuring, as opposed to the other SRL factors, did not predict any of the barriers for satisfaction.

\section{Discussion}

The aim of this research was to identify barriers to satisfaction experienced by MOOC participants and the predictors of those barriers. Participants in an ESL MOOC were asked to report their demographic and psychological characteristics and the barriers to their satisfaction with the MOOC.

Three kinds of barriers to satisfaction were identified. The results suggest that, although there are correlations among the barriers that the participants face, the predictors of the indices of the barriers are diverse. This indicates that there are different antecedents to each factor. The level of SRL, self-efficacy, extrinsic motivation, the initial behavioural intention and the age of the participant predicted different indices of the barriers. The results of the regression models suggest that to reduce barriers as a whole, course designers and facilitators should help MOOC participants to self-regulate their learning process and help them to promote their feeling of self-efficacy. Furthermore, they should be aware of the participants' initial behavioural intentions and pay closer attention to young participants.

The overall barrier score index is predicted negatively by the self-regulation indices of goal setting and study strategy and positively by the ability to manage study time. Furthermore, the overall score index of barriers is negatively predicted by the level of self-efficacy of the participants and positively by extrinsic motivation. Goal setting refers to the specification of educational goals or sub-goals in order to exert the effort required to achieve those goals (Schunk, 2005; Zimmerman, 2000). Study strategy refers to activities to improve persistence and effort-regulation in the face of academic challenges (Richardson, Abraham \& Bond, 2012). Participants who score low on goal setting and study strategies will face more barriers to satisfaction. Goal setting and strategy planning are related to the ability to plan the learning process and refer to one's decision-making on how to accomplish a learning task (Kitsantas \& Zimmerman, 2002). The ability to plan learning is related to feeling satisfied with the outcomes of web-based learning (Whipp \& Chiarelli, 2004). On the other hand, participants who allocate, schedule and allot time for learning will face barriers to satisfaction more intensely. This result is counter-intuitive, since we would expect that those who are able to manage their time will also know how to manage the barriers they face. The results, however, suggest the opposite. In the context of consumer research, Townsend and Liu (2012) discussed several conditions and factors for which planning can have a negative effect on self-regulation. If goals are far away or competing implementation intentions are available, planning can actually hinder goal achievement. The authors introduced five studies in which they found that the actual "position" concerning a long-term goal plus an interaction effect between the level of concreteness and a large goal-distance can lead to distress and finally negative effects of planning. More research in relation to the ideal amount of planning needs to be conducted to understand the mechanism that is at the root of this phenomenon. Finally, those participants who feel that they have little ability to handle learning in MOOCs and those who came to study to achieve external goals will face more barriers to satisfaction. These results are in line with the nature of the MOOC that was under investigation, which was developed for self-paced learning and did not reward the participants with external incentives. Therefore, the needs of participants who score low on selfefficacy in handling the learning process and the needs of participants who are motivated by external motivation were not fulfilled.

The three predictors of the first factor that dealt with barriers regarding interest and relevance of the course materials were indices of self-regulation. The predictors help-seeking, self-evaluation and study strategy 
suggest that we should assist learners to trust themselves, to rely less on help from peers and instructors (Richardson et al., 2012) and to improve their ability to evaluate their learning process by setting quality standards for progress (Boud, 2013). Furthermore, improving study strategies by using activities that promote persistence and effort-regulation in the face of academic challenge (Richardson et al., 2012) is recommended. It seems that the positive correlation between help seeking and the barrier lack of interestingness or relevance is counter-intuitive. The ability to seek help from instructors and friends when experiencing difficulties with academic work is a positive capacity, but in this specific MOOC, which did not provide any external or social support such as learning groups or discussion forums, the need to rely on the help of instructors or peers was experienced as a hindrance. These findings complement those of Kizilcec et al. (2017), who showed that help-seeking is associated with lower goal attainment.

To help learners to overcome the second factor, which dealt with barriers regarding lack of time or bad planning, learners should be encouraged to set educational goals or sub-goals at the beginning of a MOOC (Schunk, 2005; Zimmerman, 2000) and to better plan their study strategy. Yet, it is important to note that learners who manage their time too strictly might also face the barriers lack of time or bad planning. This is an interesting finding since one would expect that the ability to plan the schedule ahead of the course will help learners to overcome this barrier, but it seems that when measuring the subjective feeling of lack of time, participants who manage their study time more closely will also experience this barrier more intensely than those who do not plan as extensively. This again relates to the above-mentioned appropriate level of planning.

The findings of our study also show that the younger the participant, the more explicit this barrier. This finding is complementary to the findings of Henderikx et al. (2019), who focused on barriers to reaching personal learning goals and not on barriers to satisfaction. The authors argued that specific barriers predominantly appear at specific phases of life. Moreover, it can be assumed that the barrier of time management occurs with young learners due to their lack of experience in studying online and their lack of experience in self-regulating their learning. Those results suggest that course designers and instructors should pay more attention to young learners, who are more likely to face those barriers.

The third factor, lack of knowledge/technical problem, is affected by the SRL dimension of time management, the level of the external motivation, the level of self-efficacy and by the initial behavioural intentions of the participants. Participants who scored high on the SRL dimension of time management, high on the level of external motivation and low on self-efficacy were more likely to face those barriers. Participants who intended to complete only some parts of the course activities or did not know how many parts of the course they intended to complete were more likely to face those barriers than those who intended to complete all the course activities.

Time management is the ability to allocate, schedule and distribute time for learning (Yen, Tu, SujoMontes, \& Sealander, 2016). The inability of participants to manage their learning process relates to the lack of ability to handle barriers related to knowledge and technical issues. The reason for that is possibly that participants who do not know how to manage their study time do not allocte, schedule and distribute enough time to deal with technical issues and with knowledge gaps. Regarding the finding on the effect of self-efficacy, similar results have been found by Bozdoğan and Özen (2014), who showed that the feeling of competency to handle the technical aspects of learning in an online environment are critical for a successful use of information and communications technology for online courses. Bandura (1995) defined self-efficacy as "beliefs in one's capabilities to organise and execute the courses of action required for managing prospective situations." (p. 2). In this sense, lower levels of self-efficacy might hinder the ability of participants to take action on several conditions for a successful learning experience, like the acquisition of knowledge required to follow the course or the ability to handle technical issues. The positive correlation between the level of external motivation and this barrier for satisfaction suggests that learners who are motivated by external rewards will be less tolerant to face a lack of knowledge and a lack of technical abilities. The initial behavioural intentions of the participants also played a role in predicting the barrier for satisfaction. The pre-course intention to complete the full course has been identified in previous research as a predictor of the fulfilling of the course obligations and the earning of a certificate (Ho et al., 2015). Participants in open learning environments can set their own learning goals by defining their individual intention towards participating in the course (Rabin, Kalman, \& Kalz, 2019b). In line with that, an interesting finding is that the intention to complete a large portion of the course did not play a role in predicting the other barriers: neither lack of interestingness/relevance and lack of time/bad planning, nor 
the overall barrier score. Our findings indicate that behavioural intention does not predict the other barriers that learners face while trying to achieve satisfaction from participating in the course. Future research could explore how the intentions of the participants and the barriers they face affect their learning behaviour and their learning outcomes.

The gender of the participant did not play any role in determining the barriers to satisfaction. This finding is interesting since research has shown that there are differences between males and females in learning, attitudes, motivation and experiences of online learning. Muilenburg and Berge (2007) found that men are more likely to rate administrative issues, time and support as barriers to online learning compared to women. However, the results in the current study are reminiscent of the findings of Rabin et al. (2019a), who showed that there are no differences between females and males in the level of learner satisfaction while studying in a MOOC.

\section{Limitations and conclusions}

One limitation of this study is that students were asked to self-report their psychological and educational traits as well as their experience of barriers to course satisfaction. From the self-reported responses, it is hard to evaluate the actual level of barriers that the participants faced. Triangulation with additional sources such as interviews or behavioural indices could be utilised for future research. For example, a mixedmethod research set-up would be appropriate to further explore and gain a deeper understanding of quantitative self-report results (Morse, 2016). Secondly, this research focused on a fully online course that did not provide any kind of social support, such as learning groups and discussion forums. It might be interesting to see if research can replicate these findings in online courses that do provide some kind of support from peers or instructors or alternatively in courses in which it is easier for the learner to get help, such as in hybrid or blended courses. Lastly, there might be other factors that affect the level of participants' satisfaction that have not been taken into account in this research. For example, Bornschlegl and Cashman (2019) showed that interaction with other students in an online course was correlated negatively with their level of satisfaction. At the same time, the level of entertainment and the extent to which they perceived the course to contribute to their education was positively correlated with participant satisfaction. Future research could investigate the effect of indices related to student interaction, perceived entertainment and perceived contribution to education and learning on barriers to satisfaction faced by the online course participants.

In conclusion, participants in MOOCs face a variety of barriers that keep them from being satisfied with the learning process and their learning outcomes. Since the open education and MOOC context offers a different set of learning opportunities and social context compared to formal education (Rabin et al., 2019b), the role of satisfaction in the chain of intention-formation, facing barriers, coping with barriers and last but not least the realisation of initial intentions should not be underestimated. Although earlier studies have focused on general factors influencing the appearance of barriers (Henderikx, et al., 2019), this study has specifically focused on the role of learner self-regulation skills, intention, motivation, self-efficacy, age and gender with regard to their influence on the experience of barriers to satisfaction. The ability to identify those barriers to satisfaction and to recognise different groups of participants who are most likely to face different barriers can help to develop human and automated support mechanisms tailored to the needs of the learners. In that way, course designers and instructors will be able to help participants avoid and cope more effectively with those barriers to satisfaction, and subsequently help them realise their individual learning intentions.

More specifically, findings suggest that MOOCs need to make learners aware about which support infrastructures are available within a course to avoid misconceptions and manage expectations. In addition, since for most MOOCs, an increase in support is not likely to be a solution due to limited resources and the need to scale up the number of participants, the implementation of peer-support scenarios should be explored as an alternative solution to serve the needs of learners who need support (Van Rosmalen et al., 2008). Findings also suggest a need for specific interventions for young participants and participants with little learning experience in open learning environments like the MOOC discussed in this study. In addition, it would be helpful if MOOC designers and instructors develop systems and resources that help MOOC participants to self-regulate their learning process and to improve their self-efficacy. We should, though, be cautious when we integrate support systems into these learning environments (Davis, Chen, Hauff, \& 
Houben, 2016) since over-planning can also negatively impact satisfaction depending on individual characteristics and goal distances. This calls for a more tailored approach to planning support in MOOCs.

An important implication for theory development is the confirmation in our findings that satisfaction plays a different role in a non-formal learning context than in a formal learning context. While satisfaction has been identified as a bad predictor for academic achievement in a recent large-scale study (Rienties \& Toenetel, 2016), in open education contexts like MOOCs satisfaction is likely to play a more important role for self-regulation and the chain of goal setting, learning behaviour and reflection. Future research should explore these differences between formal and the non-formal educational contexts.

\section{Funding}

This research did not receive any specific grant from funding agencies in the public, commercial, or notfor-profit sectors.

\section{References}

Ajzen, I. (1991). The theory of planned behavior. Organizational Behavior and Human Decision Processes, 50(2), 179-211. https://doi.org/10.1016/0749-5978(91)90020-T

Ali, A., \& Ahmad, I. (2011). Key factors for determining students' satisfaction in distance learning courses: A study of Allama Iqbal Open University. Contemporary Educational Technology, 2(2), 118-134. https://doi.org/10.17718/tojde.10766

Alqurashi, E. (2016). Self-efficacy in online learning environments: A literature review. Contemporary Issues in Education Research-First Quarter, 9(1), 45-52. https://doi.org/10.19030/cier.v9i1.9549

Alqurashi, E. (2019). Predicting student satisfaction and perceived learning within online learning environments. Distance Education, 40(1), 133-148. https://doi.org/10.1080/01587919.2018.1553562

Artino, A. R. (2007). Motivational beliefs and perceptions of instructional quality: Predicting satisfaction with online training. Journal of Computer Assisted Learning, 24(3), 260-270. https://doi.org/10.1111/j.1365-2729.2007.00258.x

Bandura, A. (1995). Self-efficacy in changing societies. New York, NY: Cambridge University Press.

Barnard, L., Lan, W. Y., To, Y. M., Paton, V. O., \& Lai, S.-L. (2009). Measuring self-regulation in online and blended learning environments. The Internet and Higher Education, 12(1), 1-6. https://doi.org/10.1016/j.iheduc.2008.10.005

Bornschlegl, M., \& Cashman, D. (2019). Considering the role of the distance student experience in student satisfaction and retention. Open Learning: The Journal of Open, Distance and e-Learning, 34(2), 139-155. https://doi.org/10.1080/02680513.2018.1509695

Boud, D. (2013). Enhancing learning through self-assessment. London, United Kingdom: Kogan Page.

Bozdoğan, D., \& Özen, R. (2014). Use of ICT Technologies and factors affecting pre-service ELT teachers' perceived ICT self-efficacy. TOJET: The Turkish Online Journal of Educational Technology, 13(2), 186-196. Retrieved from http://www.tojet.net/articles/v13i2/13219.pdf

Brennan, K. (2013, July 24). In connectivism, no one can hear you scream: A guide to understanding the MOOC novice [Blog post]. Hybrid Pedagogy. Retrieved from http://www.rpajournal.com/studyinglearning-in-the-worldwide-classroom-research-into-edxs-first-mooc/

Breslow, L., Pritchard, D., DeBoer, J., Stump, G., Ho, A., \& Seaton, D. (2013). Studying learning in the worldwide classroom research into edX's first MOOC. Research \& Practice in Assessment, 8, $13-25$. Retrieved from-http://www.rpajournal.com/studying-learning-in-the-worldwide-classroom-researchinto-edxs-first-mooc/

Chang, S., \& Smith, R. (2008). Effectiveness of personal interaction in a learner-centered paradigm distance education class based on student satisfaction. Journal of Research on Technology in Education, 40(4), 407-426. https://doi.org/10.1080/15391523.2008.10782514

Cisel, M. (2014). Analyzing completion rates in the first French xMOOC. In U. Cress \& C. D. Kloos (Eds.), Proceedings of the Second MOOC European Stakeholders Summit (pp. 26-32. Retrieved from https://www.researchgate.net/publication/321094462_Analyzing_Completion_Rates_in_the_First_Fre nch_xMOOC 
Davis, D., Chen, G., Hauff, C., \& Houben, G. (2016). Gauging MOOC learners' adherence to the designed learning path. In T Barnes, M. Chi, M., \& M. Feng (Eds.), Proceedings of the 9th International Conference on Educational Data Mining (pp. 54-61). International Educational Data Mining Society. Retrieved from http://www.educationaldatamining.org/EDM2016/proceedings/edm2016 fullpapers.pdf

Field, A. P. (2005). Discovering statistics using SPSS (2nd ed.). London, United Kingdom: Sage.

Fishbein, M., \& Ajzen, I. (2011). Predicting and changing behavior: The reasoned action approach. New York, NY: Psychology Press.

Gannon-Cook, R. (2010). What motivates faculty to teach in distance education? A case study and metaliterature review. Lanham, MD: University Press of America.

Garrido, M., Koepke, L., Anderson, S., \& Mena, A. F. (2016). The Advancing MOOCs for Development Initiative: An examination of MOOC usage for professional workforce development outcomes in Colombia, the Philippines, \& South Africa (TASCHA Report). Seattle: University of Washington Information School. Retrieved from http://hdl.handle.net/1773/35647

Henderikx, M., Kreijns, K., Castaño Muñoz, J., \& Kalz, M. (2019). Factors influencing the pursuit of personal learning goals in MOOCs. Distance Education, 40(2), 187-204. https://doi.org/10.1080/01587919.2019.1600364

Henderikx, M., Kreijns, K., \& Kalz, M. (2017). To change or not to change? That's the question..., On MOOC-success, barriers and their implications. In C. Delgado Kloos, P. Jermann, M. PérezSanagustin, D. T. Seaton, \& S. White (Eds.), Lecture notes in computer science: Vol. 10254. Digital education: Out to the world and back to the campus (pp. 210-216). Cham, Switzerland: Springer. https://doi.org/10.1007/978-3-319-59044-8 25

Henderikx, M., Kreijns, K., \& Kalz, M. (2018). A Classification of barriers that influence intention achievement in MOOCs. In H. V. Pammer-Schindler, M. Pérez-Sanagustín \& \& M. S. Drachsler, R. Elferink (Eds.), Lecture notes in computer science (pp. 3-15). Cham, Switzerland: Springer. https://doi.org/10.1007/978-3-319-98572-5_1

Ho, A. D., Chuang, I., Reich, J., Coleman, C. A., Whitehill, J., Northcutt, C. G., .. Petersen, R. (2015). HarvardX and MITx: Two years of open online courses Fall 2012-Summer 2014. SSRN Electronic Journal, 10, 1-37. https://doi.org/10.2139/ssrn.2586847

Horvat, A., Dobrota, M., Krsmanovic, M., \& Cudanov, M. (2015). Student perception of Moodle learning management system: A satisfaction and significance analysis. Interactive Learning Environments, 23(4), 515-527. https://doi.org/10.1080/10494820.2013.788033

Keller, J. (1983). Motivational design of instruction. In C. Reigeluth (Ed.), Instructional design theories and models: An overview (pp. 386-434). Hillsdale, NJ: Lawrence Erlbaum.

Khalil, H., \& Ebner, M. (2014). MOOCs completion rates and possible methods to improve retention: A literature review. In Proceedings of EdMedia 2014- World Conference on Educational Media and Technology (pp. 1305-1313). New York, NY: AACE.

Kitsantas, A., \& Zimmerman, B. J. (2002). Comparing self-regulatory processes among novice, nonexpert, and expert volleyball players: A microanalytic study. Journal of Applied Sport Psychology, 14(2), 91-105. https://doi.org/10.1080/10413200252907761

Kizilcec, R. F., Piech, C., \& Schneider, E. (2013). Deconstructing disengagement: Analyzing learner subpopulations in massive open online courses. In Proceedings of the Third International Conference on Learning Analytics and Knowledge (pp. 170-179). New York, NY: ACM. Retrieved from http://dl.acm.org/citation.cfm?id=2460330

Kizilcec, R. F., Perez-Sanagustín, M., \& Maldonado, J. J. (2017). Self-regulated learning strategies predict learner behavior and goal attainment in massive open online courses. Computers \& Education, 104, 18-33. https://doi.org/https://doi.org/10.1016/j.compedu.2016.10.001

Koller, D., Ng, A., Do, C., \& Chen, Z. (2013). Retention and intention in massive open online courses: In depth. Educause Review, 48(3), 62-63. Retrieved from http://www.educause.edu/ero/article/retentionand-intention-massive-openonline-courses-depth-0

Kuo, Y. C., Walker, A. E., Schroder, K. E. E., \& Belland, B. R. (2014). Interaction, Internet self-efficacy, and self-regulated learning as predictors of student satisfaction in online education courses. Internet and Higher Education, 20, 35-50. https://doi.org/10.1016/j.iheduc.2013.10.001

Lajoie, S. P., \& Azevedo, R. (2006). Teaching and learning in technology-rich environments. In P. Alexander \& P. Winne (Eds.), Handbook of educational psychology (2nd ed., pp. 803-822). Mahwah, NJ: Lawrence Erlbaum Associates.

Lee, Y., \& Choi, J. (2013). A structural equation model of predictors of online learning retention. The Internet and Higher Education, 16, 36-42. https://doi.org/10.1016/J.IHEDUC.2012.01.005 
Levy, Y. (2007). Comparing dropouts and persistence in e-learning courses. Computers \& Education, 48(2), 185-204. https://doi.org/10.1016/J.COMPEDU.2004.12.004

Liaw, S., \& Huang, H. (2011). Exploring learners' acceptance toward mobile learning. In T. Teo (Ed.), Technology acceptance in education (pp. 145-157). Rotterdam, The Netherlands: Sense Publishers.

Littlejohn, A., Hood, N., Milligan, C., \& Mustain, P. (2016). Learning in MOOCs: Motivations and selfregulated learning in MOOCs. The Internet and Higher Education, 29, 40-48. https://doi.org/10.1016/j.iheduc.2015.12.003

Margaryan, A., Bianco, M., \& Littlejohn, A. (2015). Instructional quality of massive open online courses (MOOCs). Computers and Education, 80, 77-83. https://doi.org/10.1016/j.compedu.2014.08.005

Morris, N., Hotchkiss, S., \& Swinnerton, B. (2015). Can demographic information predict MOOC learner outcomes? In D. Ifenthaler (Ed.), Digital Workplace Learning: Bridging Formal and Informal Learning with Digital Technologies: Proceedings of the Third European MOOC Stakeholders Summit (pp. 199-207). Retrieved from http://eprints.whiterose.ac.uk/86184/

Morse, J. (2016). Mixed method design: Principles and procedures. Walnut Creek, CA: Left Coast Press.

Muilenburg, L. Y., \& Berge, Z. L. (2007). Student barriers to online learning: A factor analytic study. Distance Education, 26(1), 29-48. https://doi.org/10.1080/01587910500081269

Naveh, G., Tubin, D., \& Pliskin, N. (2012). Student satisfaction with learning management systems: a lens of critical success factors. Technology, Pedagogy and Education, 21(3), 337-350. https://doi.org/10.1080/1475939X.2012.720413

Onah, D., Sinclair, J., \& Boyatt, R. (2014). Dropout rates of massive open online courses: Behavioural patterns. In L. Gómez Chova, A. López Martínez, \& I. Candel Torres (Eds.), Proceedings of EDULEARN14: The 6th International Conference on Education and New Learning Technologies (pp. 5825-5834). Valencia, Spain: IATED. Retrieved from https://library.iated.org/publications/EDULEARN14

Park, J., \& Society, H. C. (2009). Factors influencing adult learners' decision to drop out or persist in online learning. Journal of Educational Technology \& Society, 12(4), 207-217. Retrieved from https://www.jstor.org/stable/10.2307/jeductechsoci.12.4.207

Pintrich, P. (1991). A manual for the use of the Motivated Strategies for Learning Questionnaire (MSLQ). Ann Arbor: The University of Michigan. Retrieved from ERIC database. (ED338122)

Rabin, E., Kalman, Y. M., \& Kalz, M. (2019a). Predicting learner-centered MOOC outcomes: Satisfaction and intention-fulfillment. International Journal of Educational Technology in Higher Education, 16, art. 14. https://doi.org/10.1186/s41239-019-0144-3

Rabin, E., Kalman, Y. M., \& Kalz, M. (2019b). The cathedral's ivory tower and the open education bazaar: Catalyzing innovation in the higher education sector. Open Learning: The Journal of Open, Distance and e-Learning, 35(1), 82-99. https://doi.org/10.1080/02680513.2019.1662285

Reich, J. (2014). MOOC completion and retention in the context of student intent. Educause Review Online. Retrieved from http:/www.educause.edu/ero/article/mooc-completion-andretention-contextstudent-intent

Reich, J., \& Ruipérez-Valiente, J. A. (2019). The MOOC pivot. Science, 363(6423), 130-131. https://doi.org/10.1126/science.aav7958

Rienties, B., \& Toetenel, L. (2016). The impact of learning design on student behaviour, satisfaction and performance: A cross-institutional comparison across 151 modules. Computers in Human Behaviour, 60, 333-341. https://doi.org/10.1016/j.chb.2016.02.074

Richardson, M., Abraham, C., \& Bond, R. (2012). Psychological correlates of university students' academic performance: A systematic review and meta-analysis. Psychological Bulletin, 138(2), 353387. https://doi.org/10.1037/a0026838

Roca, J. C., Chiu, C.-M., \& Martínez, F. J. (2006). Understanding e-learning continuance intention: An extension of the Technology Acceptance Model. International Journal of Human-Computer Studies, 64(8), 683-696. https://doi.org/10.1016/j.ijhcs.2006.01.003

Ryan, R., \& Deci, E. (2000). Self-determination theory and the facilitation of intrinsic motivation, social development, and well-being. American Psychologist, 55(1), 68-78. https://doi.org/10.1037/0003066X.55.1.68

Schunk, D. H. (2005). Self-regulated learning: The educational legacy of Paul R. Pintrich. Educational Psychologist, 40(2), 85-94. https://doi.org/10.1207/s15326985ep4002_3

Shen, D., Cho, M.-H., Tsai, C.-L., \& Marra, R. (2013). Unpacking online learning experiences: Online learning self-efficacy and learning satisfaction. The Internet and Higher Education, 19, 10-17. https://doi.org/10.1016/J.IHEDUC.2013.04.001 
Stoffelsen, J., \& Diehl, P. (2007). Handboek levensfasebewust personeelsbeleid [Handbook for life-stage conscious personnel management]. Alphen aan den Rijn, The Netherlands: Kluwer.

Townsend, C., \& Liu, W. (2012). Is planning good for you? The differential impact of planning on selfregulation. Journal of Consumer Research, 39(4), 688-703. https://doi.org/10.1086/665053

Van Rosmalen, P., Sloep, P. B., Brouns, F., Kester, L., Berlanga, A., Bitter, M., \& Koper, R. (2008). A model for online learner support based on selecting appropriate peer tutors. Journal of Computer Assisted Learning, 24(6), 483-493. https://doi.org/10.1111/j.1365-2729.2008.00283.x

Wang, Y., \& Baker, R. (2018). Grit and intention: Why do learners complete MOOCs? The International Review of Research in Open and Distributed Learning, 19(3). https://doi.org/10.19173/irrodl.v19i3.3393

Whipp, J. L., \& Chiarelli, S. (2004). Self-regulation in a web-based course: A case study. Educational Technology Research and Development, 52(4), 5-21. https://doi.org/10.1007/BF02504714

Yen, C. J., Tu, C.-H., Sujo-Montes, L., \& Sealander, K. (2016). A predictor for PLE management: Impacts of self-regulated online learning on students' learning skills. Journal of Educational Technology Development \& Exchange, 9(1), 29-48. https://doi.org/10.18785/jetde.0901.03

Yukselturk, E., \& Yildirim, Z. (2008). Investigation of interaction, online support, course structure and flexibility as the contributing factors to students' satisfaction in an online certificate program. Journal of Educational Technology \& Society, 11, 51-65. https://doi.org/10.2307/jeductechsoci.11.4.51

Zalli, M., Nordin, H., \& Hashim, R. (2019). The role of self-regulated learning strategies on learners` satisfaction in massive open onlne courses (MOOCs). International Journal of Innovative Technology and Exploring Engineering, 8(10), 2286-2290. https://doi.org/10.35940/ijitee.J1138.0881019

Zimmerman, B. J. (2000). Attaining self-regulation: A social cognitive perspective. In M. Boekaerts, P. Pintrich, \& M. Zeidner (Eds.), Handbook of self-regulation (pp. 13-39). New York, NY. Academic Press.

Zimmerman, B. J. (2002). Becoming a self-regulated learner: An overview. Theory into Practice, 41(2), 64-70). https://doi.org/10.1207/s15430421tip4102_2

Corresponding author: Eyal Rabin, eyalra@openu.ac.il

Copyright: Articles published in the Australasian Journal of Educational Technology (AJET) are available under Creative Commons Attribution Non-Commercial No Derivatives Licence (CC BY-NC-ND 4.0). Authors retain copyright in their work and grant AJET right of first publication under CC BY-NC-ND 4.0.

Please cite as: Rabin, E., Henderikx, M., Kalman, Y. M., \& Kalz, M. (2020). What are the barriers to learners' satisfaction in MOOCs and what predicts them? The role of age, intention, self-regulation, self-efficacy and motivation. Australasian Journal of Educational Technology, 36(3), 119-131. https://doi.org/10.14742/ajet.5919 